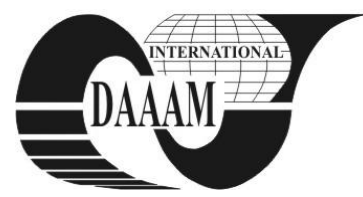

Annals of DAAAM for 2011 \& Proceedings of the 22nd International DAAAM Symposium, Volume 22, No. 1, ISSN 1726-9679 ISBN 978-3-901509-83-4, Editor B. Katalinic, Published by DAAAM International, Vienna, Austria, EU, 2011 Make Harmony between Technology and Nature, and Your Mind will Fly Free as a Bird

\title{
A NEW MODEL IN CYBER ENTERPRISE MANAGEMENT BASED ON ERP
}

\author{
DANESHMAND MALAYERI, A[min]
}

\begin{abstract}
This paper is mainly discussing about new paradigm of Enterprise Resource Planning (ERP) in cyber space. This model has been presented in order to increasing usage of ERP in organizational and enterprise management.

Using ERP systems in Information Technology Management has been increased in IT activities for companies and organizations which they are involving in IT projects. Combination of ERP and web environment is our main focus in this paper. This kind of ERP implementation can make bet-ter results for managers, especially in their strategic planning for future of their organization by monitoring their system by using web. "Cyber ERP" implementation is this technology for management in companies and organizations with some advantages and benefits such as model sharing, disaster management and others. All of these benefits with Cyber ERP has been introduced in this paper.

Key words: ERP, enterprise management, organizational management, cyber ERP
\end{abstract}

\section{INTRODUCTION}

Using new enterprise information systems has been increased and developed recently. Some of these systems and modules does not cover and support all of essential procedures in organizational systems. One of the most applicable systems in organizational management is Enterprise Resource Planning (ERP) that support and cover all of recent procedures in organizations. The sample schematic board of an ERP system has been shown in Figure 1.

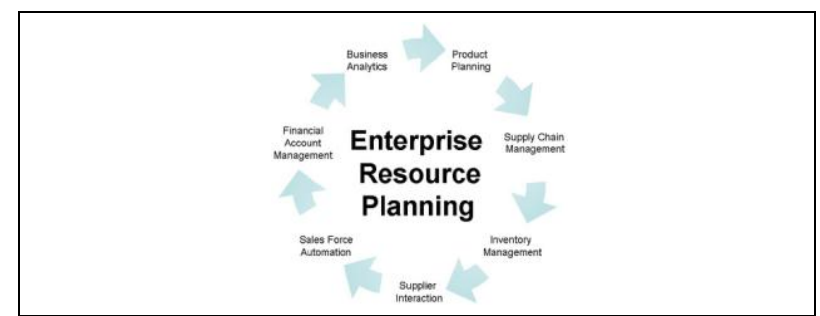

Fig. 1. Schematic of an ERP system

Usually, these systems work in a system-based or offline mode. This workflow has some various wanted or unwanted problems and defaults. Some parts of an ERP system should be contacted to an online environment to support better than usual (offline) mode. In other words, some of ERP system parts have direct relation with updating and supporting systems via web-based services. In the next sections, these procedures have been proceed and described.

\section{PARTS OF AN ERP SYSTEM}

Parts of an ERP system can be gathered and described as below :
A) Business Analyzing
B) Product Planning
C) Supply Chain Management (SCM)
D) Inventory Management
E) Supplier Interaction
F) Sales Automation
G) Financial Account Managing

These parts are main base of an ERP system, however; they can be increased up to condition changes. All of these parts are covered by a full package as shown in Figure 2.

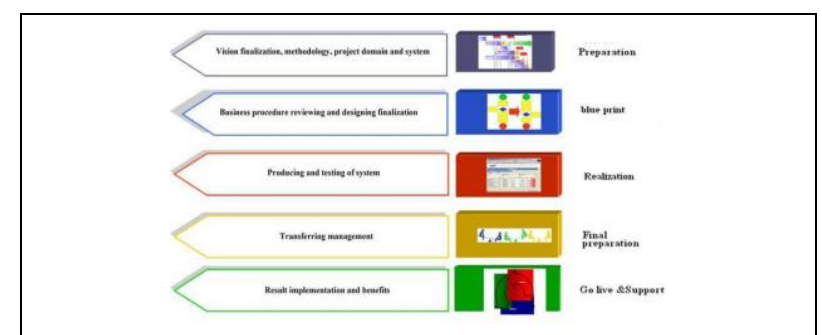

Fig. 2. ERP workflow package

Each part is belong to one of these workflow package. Collecting of these modules can supply ERP system as the full support environment for organizational and enterprise management.

It can be classified that each part of ERP system as one of ERP workflow as below model:

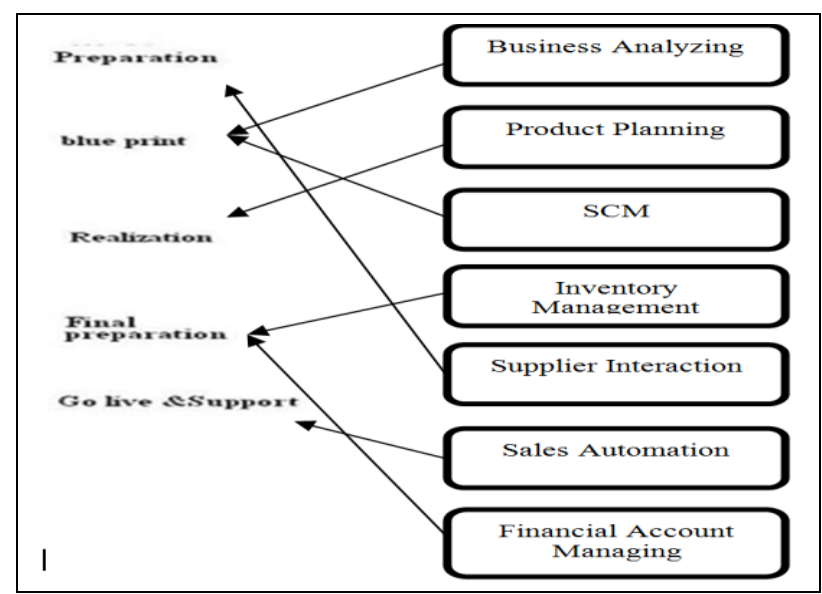

Fig. 3. Model of ERP system and ERP workflow combination

This model can generalize to offline and online modes. In offline mode, this combination and classification is without moderator or exchange. Offline using of this model has been shown in figure 4 . In this 
figure, ERP System elements has been shown with "A" and its workflow with" $\mathrm{B}$ ". processing is come from " $\mathrm{A}$ " to "B" for final monitoring.

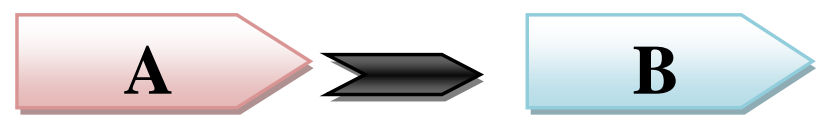

Fig. 4. Offline ERP System and Workflow Monitoring

\subsection{Online feature of ERP system and its workflow}

In online mode, Combination of ERP Schematic and its workflow is with base on "online moderator". This moderator is catalyst in online environment for ERP combination system. Using this moderator has been shown schematically in Figure 5. (module " $\mathrm{C}$ " is as moderator)

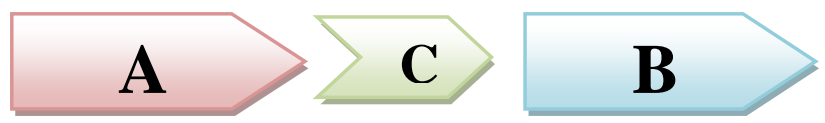

Fig. 5. Online ERP System and Workflow Monitoring

\section{CYBER ERP BRIEF SURVEY}

Using parts of II can be developed in a cyber environment. Nowadays, some organizations like using this kind of ERP systems. After data gathering and Blue print state, software designing is based on web programming. Some unified process methodologies are flexible with designing and developing by under supporting of web services.

Cyber ERP system is with some extra benefits than usual one.

\section{CYBER ERP ELEMENTS AND ADVANTAGES}

Cyber ERP programming let users and programmers share their experiences from the first level of implementation. The main subject of using these ERP systems is their infrastruc-tures. These are up to internet connections, user experiences and hardware/software requirements. Some local ERP systems are not suitable for changing to a global and pattern.

With sharing of sources in a cyber ERP system, system ana-lyzers should be informed about best practice(s) which has been used in system. Some best practice methodologies is suitable for small business and organizations. Maybe using these systems in a large scale business make harmful results without analyzers notification.

Benefits of ERP source sharing can improve experiences of managers that they will start their ERP implementations.

Also, localization and copyright laws infrastructures should be considered in local and especially global ERP systems.

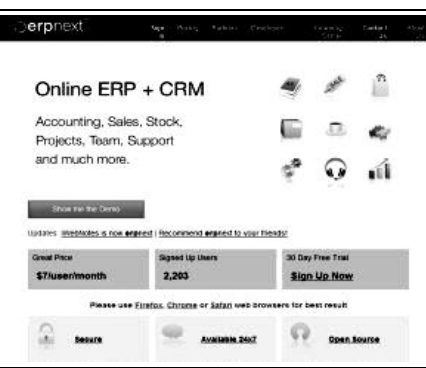

Fig. 6. Sample Online ERP Schematic

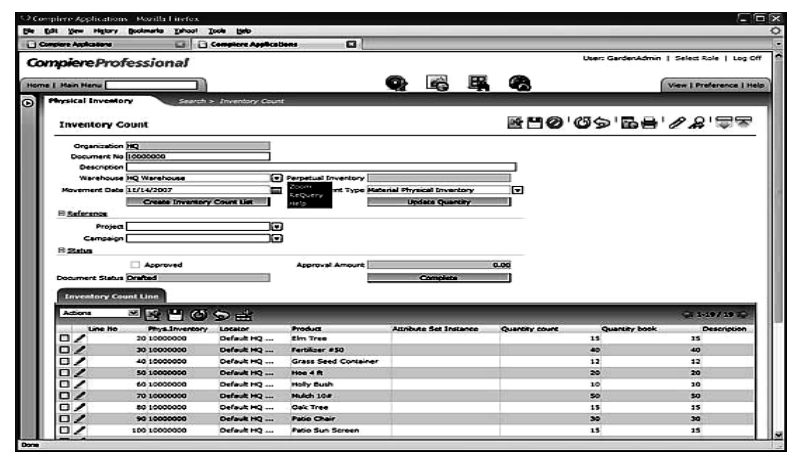

Fig. 7. Sample online ERP Work flow chart

\section{CONCLUSION}

ERP implementation is essential for new management per-forming. Best Practice defining, effective data gathering and performing suitable software engineering systems can make a powerful virtual management system for managers in organizations. In this paper, we introduced a new metho-dology for ERP systems entitle" Cyber ERP". Providing infrastructures of using this system is the basically subject in its implementation. Some companies has been used this kind of ERP systems but the main problem is not to providing all of conditions for performing and implementation of this system in Iran organizations.

Model Sharing is the most important ability of Cyber ERP for transferring experiences of managers and involved persons.

\section{REFERENCES}

Daft, R. L. (2001). Organization Theory and Design, $6^{\text {th }}$ edition, South Western College Publishing, Cincinnati, Ohio

Davenport, T.H. (1998). Putting the Enterprise into the Enterprise System, Harvard Business Review, pp. 121-131

Emami.S, (2009). what is ERP, journal of Informatics Society of Iran, 187 , pp.36-47

Evans, M. and S. Bragg, (1997). Ovum Evaluates ERP for Manufactur-ers, Ovum' Report

Everdingen, Y. Hillergersberg, J. and E. Waarts, (2000). ERP Adop-tion by European Midsize Companies, Communication of the ACM, 43(3), pp. 27-31

Fisher, D.M., Kiang, M.Y., Fisher, S.A. \& R.T. Chi, (2004). Eva-luating Mid-Level ERP Software, Journal of Computer Informa-tion Systems, 45(1), pp. 38-46

Halland, C.P. and B. Light, (1999). A Critical Success Factors Model for ERP Implementation, IEEE Software, pp. 30-36

King, W. (2005). Ensuring ERP Implementation Success, Informa-tion Systems Management, 22(3), pp.83-85

Lall, V. \& S. Teyarachakul (2006). Enterprise Resource Planning (ERP) System Selection: A Data Envelopment Analysis (DEA) Approach, Journal of Computer Information Systems, 47(1), pp.123-127

Laughlin, S.P. (1999). An ERP Game Plan, Information Technolo-gy, pp.23-26.

Lawrence, P.R. \& J.W. Lorsch (1967). Differentiation and Integra-tion in Complex Organizations, Administrative Science Quarterly, 12, pp.1-47.

Nah, F.F. and S. Delgado (2006). Critical Success Factors for Enter-prise Resource Planning Implementation and Upgrade, Journal of Computer Information Systems, 47, 2006, pp. 99- 113.

Pereira, R.E. (1999). Resource View Theory Analysis of SAP as a Source of Competitive Advantage for Firms, Database, 30(1), 1999, pp. 38-46

***http://www.isi.org.ir_, official website of Informatics Society of Iran 